\title{
Activities of Acetylcholinesterase, Oxidative and Nitrosative Stress Markers in Clarias gariepinus Exposed to 'Uproot', a Glyphosate-Based Herbicide
}

\author{
Osioma E..$^{*}$ and Ejoh A.S. ${ }^{2}$ \\ ${ }^{1}$ Department of Biochemistry, Faculty of Science, Federal University Otuoke, Bayelsa State, Nigeria \\ ${ }^{2}$ Department of Biological Sciences, Covenant University Ota, Nigeria
}

${ }^{*}$ Corresponding Author

Received: $24^{\text {th }}$ December, 2020

Accepted: $12^{\text {th }}$ February, 2021

Published online: $1^{\text {st }}$ March, 2021

https://doi.org/10.33745/ijzi.2021.v07i01.006

\begin{abstract}
In this study, Clarias gariepinus were exposed to different concentrations $(60,80$ and $100 \mathrm{mg} / \mathrm{L})$ of Uproot, a glyphosate-bas ed herbicide and the activities of acetylcholinesterase (AChE), hepatic enzyme markers, oxidative and nitrosative stress markers were determined in serum, gills, liver and brain by using standard assays. Results showed that AChE activity was not significantly inhibited. Activities of ALT, AST and ALP increas ed (P < $0.05)$ with increasing exposures. For SOD, elevated $(\mathrm{P}<0.05)$ activities were observed in all tissues at $60 \mathrm{mg} / \mathrm{L}$ exposure, but decreased at $80 \mathrm{mg} / \mathrm{L}$ and $100 \mathrm{mg} / \mathrm{L}$ concentrations. The activity of CAT reduced significantly $(\mathrm{P}<$ 0.05 ) in brain at $100 \mathrm{mg} / \mathrm{L}$ exposure. Increased production of $\mathrm{NO}$ was observed in gill and brain whereas in serum it is increased. GPx was elevated in gills and reduced in brain and liver. Gills showed lower MDA concentrations. GST was el evated in liver and brain, while total protein reduced $(P<0.05)$ in serum, gill and liver with increasing concentrations of exposure. The impaired activities of antioxidant enzymes and induction of NO suggest a disruption of normal antioxidant response in Clarias gariepinus exposed to glyphosate, and these activities could be used as biomarkers in aquatic environmental contamination.
\end{abstract}

Keywords: Uproot, Glyphosate, Clarias gariepinus, Nitric oxide, Antioxidant enzymes

Citation: Osioma E. and Ejoh A.S.: Activities of acetylcholinesterase, oxidative and nitrosative stress markers in Clarias gariepinus exposed to 'Uproot', a glyphosate-based herbicide. Intern. J. Zool. Invest. 7 (1): 51-66, 2021. https://doi.org/10.33745/ijzi.2021.v07i01.006

\section{Introduction}

The use of agricultural herbicides in weed control in farms over the traditional weeding method cannot be over emphasized.
Herbicides applicability in crop fields to control weeds improves productivity of farm produce, leading to the cultivation of large 
piece of land. However, such chemicals, when employed in farmland to contain weeds could also contaminate the environment; and for aquatic habitat, pollution by these herbicides is due to leaching and water run-off from treated areas which basically poses a great risk to non - target aquatic organism especially fishes of commercial importance (Oruc et al., 2004; Dey et al., 2016).

Exposure of aquatic lives to herbicides directly or indirectly, can induce an increase in the production of reactive oxygen species (ROS) and also modify the antioxidant defense. Uproot, is the conventional glyphosate-based herbicide, employed by farmers in Otuoke, Bayelsa State, Nigeria. Glyphosate is an isopropylamine salt of glycine, a non-selective herbicide which was introduced into the agricultural market in 1974 for the management of weeds in cultivars (Duke and Powles, 2008). As a result of the large-scale use of Uproot in our locality and the proximity of crop and fish culture areas, glyphosate which leached into aquatic environment could induce changes in several biochemical variables which could be employed to evaluate fish health. These modifications may be in the altered function of cells, tissues, as well as physiology and behavior of the organisms (Parvez and Raisuddin, 2005). Exposure to glyphosate can cause a greater amount of pro - oxidants than antioxidants, resulting in the intensity of ROS generation and/or altering antioxidant defense (Ahmad et al., 2000; Monserrat et al., 2007). To neutralize the effect of ROS, animals have an established antioxidant defense pathway of antioxidant enzymes such as superoxide dismutase (SOD), catalase (CAT), glutathione peroxidase ( $\mathrm{GPx}$ ), glutathione -Stransferase (GST) as well as non-ezymatic antioxidants such as reduced glutathione (GSH).

Recently, nitric oxide has been reported as an antioxidant (Radi, 2018). It reacts with superoxide radical to form peroxynitrite (ONOO-) which is commonly associated with a pro-oxidant response and scavenge lipid peroxyl radical $\left(\mathrm{LOO}^{*}\right)$ that is viewed as the antioxidant response (Goss et al., 1997). Inhibition of acetylcholinesterase (AChE) activity by formulations containing glyphosate have been reported by several studies (Glusczak et al., 2006; Glusczak et al., 2007; Modesto and Martinez, 2010 a)

In the aquatic habitat, teleost, according to Sancho et al. (2000) has proven to be a good model to appraise the toxicity and consequences of contaminants on animals, since the biochemical responses are identical to those of mammals and other vertebrates. Clarias gariepinus found in rivers and swamp in the Niger Delta regions of Nigeria are of economic value, source of protein to many families and is also treated as a potential bioindicator species (Osioma and Iniaghe, 2019). These biochemical markers established association of the sample with definite groups of chemical compounds and allows causeeffect relativity to be established at an initial stage of pollution (Osioma et al., 2013). Thus, evaluation of changes in biochemical enzymes as biomarker in Clarias gariepinus exposed to different concentrations of glyphosate will support to provide a link between the effect of xenobiotic exposure and risk assessment process which could be utilized in documentary toxin interaction with biological system. Hence, in the present study, the activities of antioxidant enzymes (SOD, CAT, GPx, GST), acetylcholinesterase (AChE), hepatic enzyme markers, alanine and 
aspartate aminotransferase, and alkaline phosphatse (ALT, AST and ALP), concentrations of total protein (TP), nitric oxide (NO), reduced glutathione (GSH) and malondialdehyde (MDA) in serum and selected tissues (gills, liver and brain) of Clarias gariepinus exposed to different concentrations of glyphosate herbicide, were investigated.

\section{Materials and Methods}

\section{Collection of fish specimens}

Thirty (30) specimens of African catfish (Clarias gariepinus) were procured from a commercial fish pond (Rubber Pond) along Azikoro Expressway, Yenagoa, Bayelsa State, Nigeria. They were transported on the same day to the laboratory in a well ventilated container with the pond water to avoid injury. Fish were left to acclimatize in the congenial laboratory condition for 14 days in aquaria of $200 \mathrm{~L}$ capacity. They were fed once a day with commercial fish pellets during both acclimation and exposure periods

\section{Experimental design}

Uproot, a herbicide containing isopropylammonium salt of glyphosate as active ingredient (equivalent to $360 \mathrm{~g} / \mathrm{L}$ ) was purchased from a local trader at Otuoke, Bayelsa State, Nigeria. In preparing the required doses used for the experiment, 10 $\mathrm{mL}$ of the stock was taken and made up to 500 $\mathrm{mL}$ with distilled water. From this dilution, the required doses $(60 \mathrm{mg} / \mathrm{L}, 80 \mathrm{mg} / \mathrm{L}$ and $100 \mathrm{mg} / \mathrm{L}$ ) of glyphosate were calculated and multiplied by capacity of the aquaria, $20 \mathrm{~L}$.

Treatment with herbicide commenced on the $3^{\text {rd }}$ week. Fish were divided into four groups (A, B, C and D) comprising five fish per group $(n=5)$ and separated into $20 \mathrm{~L}$ capacity aquaria. Group A served as control without glyphosate exposure. Groups B, C and D were exposed to $60 \mathrm{mg} / \mathrm{L}, 80 \mathrm{mg} / \mathrm{L}$ and $100 \mathrm{mg} / \mathrm{L}$ glyphosate, respectively. The water was changed every $24 \mathrm{~h}$ and exposure was repeated for 14 days. Experiments were conducted at natural photoperiod.

Preparation of serum and tissue supernatants

At the end of the experiment, fish were anaesthetized and blood collected by caudal arterial puncture from each fish with the help of a $5 \mathrm{~mL}$ syringe. A portion of the blood sample was put into EDTA container for the estimation of blood reduced glutathione, while the remaining blood sample was introduced into a $5 \mathrm{~mL}$ plain tube. The fish were euthanized by spinal section and decapitation, and then, dissected for tissue collection. Gills, liver and brain were washed in $0.75 \%$ saline solution, soaked with filter paper and stored at $-20 \mathrm{C}$ for biochemical analysis.

The remaining portion of the collected fish blood was allowed to clot for about $20 \mathrm{~min}$ at room temperature (27 C). The clotted blood samples were dislodged and centrifuged at $\mathrm{x} 5000 \mathrm{~g}$ for $15 \mathrm{~min}$ to obtain serum, which was stored frozen at - 20 C until analyzed.

$0.5 \mathrm{~g}$ of each tissue (gills, liver and brain) was homogenized separately in $4.5 \mathrm{~mL}$ of ice cold $50 \mathrm{mM}$ phosphate buffer ( $\mathrm{pH} 7.2$ ). The resulting homogenate was centrifuged at $\mathrm{x} 4000 \mathrm{~g}$ for $10 \mathrm{~min}$. The supernatant was decanted into a $5 \mathrm{~mL}$ sterilized plain tube. This was immediately stored in deep freezer at $-20 \mathrm{C}$ for further biochemical analysis.

\section{Biochemical analysis}

Total protein determination

Total protein content in serum and tissue samples was determined spectrophoto- 
metrically by the method of Doumas et al. (1981). The principle was based on the formation of purple complex when protein reacts with cupric ions in an alkaline solution. The intensity of the violet colour was proportional to the amount of protein present in the sample measured at $540 \mathrm{~nm}$.

\section{Superoxide dismutase assay}

The superoxide dismutase activity was determined as described by Misra and Fridovich (1972). This method was based on inhibiting the radical superoxide reaction with epinephrine. The superoxide anion $\left(\mathrm{O}_{2}^{--}\right)$ substrate for SOD was generated in the oxidation of epinephrine at alkaline $\mathrm{pH}(\mathrm{pH}$ 10.2 ) by the action of oxygen on epinephrine. Briefly, to $0.2 \mathrm{~mL}$ of homogenate, $2.5 \mathrm{~mL}$ of $0.05 \mathrm{M}$ carbonate buffer (pH 10.2) was added. The reaction was initiated by adding $0.3 \mathrm{~mL}$ of freshly prepared $0.3 \mathrm{mM}$ of epinephrine. This was mixed by inversion. The reference cuvette contained $2.5 \mathrm{~mL}$ of the buffer, $0.2 \mathrm{~mL}$ of distilled water and $0.3 \mathrm{~mL}$ of the substrate (epinephrine). The per cent inhibition (\% I) is hyperbolic with respect to the SOD activity. Increase in absorbance was monitored at 480 $\mathrm{nm}$ at interval of $30 \mathrm{sec}$ for $150 \mathrm{sec}$. The activity was expressed in unit/g tissue.

\section{Catalase assay}

The method of Kaplan and Groves (1972) was employed in the determination of catalase activity. This was carried out by monitoring the breakdown of hydrogen peroxide in the reaction mixture by changes in the absorbance at wavelength of $360 \mathrm{~nm}$ for 70 sec. To $2 \mathrm{~mL}$ of the prepared sample, $1 \mathrm{~mL}$ of $\mathrm{H}_{2} \mathrm{O}_{2}$ substrate was added to the reaction cuvette. The reference cuvette contained $1 \mathrm{~mL}$ of $\mathrm{H}_{2} \mathrm{O}_{2}$ and $2 \mathrm{~mL}$ of water. Catalase activity was expressed as unit/g tissue.
Estimation of blood reduced glutathione

The reduced glutathione concentration of blood was estimated using the method of Beutler (1984). The sulfhydryl group of GSH reacted with DTNB (5,5-dithio-bis-2nitrobenzoic acid) and produced a yellow coloured 5-thio-2-nitrobenzoic acid (TNB). The absorbance of TNB at $412 \mathrm{~nm}$ provided an estimation of GSH in the sample. Briefly, 1.8 $\mathrm{mL}$ of distilled water was added to $0.2 \mathrm{~mL}$ of blood sample and was followed by the addition of $3 \mathrm{~mL}$ of precipitating solution. The mixture was allowed to stand for $5 \mathrm{~min}$ and filtered. To $8 \mathrm{~mL}$ of phosphate solution was added $2 \mathrm{~mL}$ of the filtrate and $1 \mathrm{~mL}$ of DTNB solution. The blank was prepared with $8 \mathrm{~mL}$ of phosphate solution, $2 \mathrm{~mL}$ of dilute precipitating solution (3 parts to 2 parts of distilled water), and $1 \mathrm{~mL}$ of DTNB reagent. The absorbance was read at $412 \mathrm{~nm}$ against the reagent blank. The concentration of blood GSH was calculated as; Blood Reduced GSH $(\mathrm{mg} \%$ in blood $)=310.4 \times \varepsilon \times$ Absorbance, Where, $\varepsilon$ is the correction factor $=0.542$.

\section{Estimation of tissue reduced glutathione}

The reduced glutathione levels in the supernatant of tissues were determined using the procedure of Ellman (1959). The principle is as outlined above for blood GSH. Tissue supernatant $(0.5 \mathrm{~mL})$ was added to $2 \mathrm{~mL}$ of $10 \% \quad(\mathrm{w} / \mathrm{v})$ trichloroacetic acid, mixed thoroughly and centrifuged at $x 5000 \mathrm{~g}$. Then, $1 \mathrm{~mL}$ of supernatant was mixed with $0.5 \mathrm{~mL}$ Ellman's reagent and $3 \mathrm{~mL}$ of $0.2 \mathrm{M}$ phosphate buffer ( $\mathrm{pH}$ 8.0). The absorbance was read against the blank at $412 \mathrm{~nm}$. A series of standards were prepared along with a blank containing $3.5 \mathrm{~mL}$ of buffer. The concentration of reduced GSH in 1 mole of GSH/g of wet 
tissue was extrapolated from a standard calibration plot.

\section{Glutathione peroxidase assay}

The activity of GPx in tissue supernatant was evaluated spectrophotometrically as described by Moin (1986). The principle of the reaction was based on the production of oxidized glutathione (GSSG) upon reduction of organic peroxide by GPx, which was recycled to its reduced state by the enzyme glutathione reductase. The assay mixture contained 0.8 $\mathrm{mL}$ of $0.1 \mathrm{M}$ Tris - $\mathrm{HCl}(\mathrm{pH} \mathrm{8.9)}$ with $12 \mathrm{mM}$ sodium azide and $6 \mathrm{mM}$ EDTA, $0.2 \mathrm{~mL}$ of tissue supernatant, $0.1 \mathrm{~mL}$ of $0.01 \mathrm{M} \mathrm{5,5-}$ dithiobis -2- nitrobenzoic acid, $0.1 \mathrm{~mL}$ of 20 $\mathrm{mM} \mathrm{t}$ - butylhydroxyperoxide, and $0.1 \mathrm{~mL}$ of $4.8 \mathrm{mM} \mathrm{GSH}$. The decrease in absorbance at $412 \mathrm{~nm}$ was followed spetrophotometrically. GPx enzymatic activity was expressed as $\mu \mathrm{mol} / \mathrm{mg}$ tissue $/ \mathrm{min}$.

\section{Glutathione - S- transferase assay}

The activities of glutathione S- transferase (GST) in the supernatant of gills, liver and brain tissues were assayed by the method of Habig et al. (1974). GST catalysed the conjugation of L-glutathione to 1-chloro-2,4dinitrobenzene (CDNB) through the thiol group of the glutathione. The formation of the GS-DNB conjugate was proportional to the enzyme activity and can be used for photometric GST activity determination. The rate of increase in the absorption of GS-DNB conjugate at $340 \mathrm{~nm}$ was directly proportional to the GST activity in the sample. The reaction mixture was prepared by mixing $1.5 \mathrm{~mL}$ sodium phosphate buffer $(0.1 \mathrm{M} \mathrm{pH} 6.5), 0.2$ $\mathrm{mL}$ GSH $(9.2 \mathrm{mM}), 0.02 \mathrm{~mL}$ CDNB $(0.1 \mathrm{M})$ and $0.1 \mathrm{~mL}$ of the sample (homogenate). The reaction solution without the supernatant was used as the blank. GST activity was expressed as $\mu \mathrm{mol} / \mathrm{mg}$ tissue $/ \mathrm{min}$.

\section{Nitric oxide determination}

Nitric oxide was determined in serum, gills, liver and brain tissues by the method of Green et al. (1982). The principle was based on the enzymatic conversion of nitrate to nitrite by nitrate reductase, which was followed by a 2 step diazotization reaction by Griess reaction. The formed nitrous acid diazotise sulphanilamide and the product was coupled with N- (1- naphthyl) ethylenediamine to form a bright reddish-purple colour which absorbed strongly at $540 \mathrm{~nm}$. The assay mixture contains $0.5 \mathrm{~mL}$ of sample supernatant with equal volume of Griess reagent $[(0.1 \mathrm{~mL}$ sulfanilic acid reagent $(0.33 \%$ in $20 \%$ glacial acetic acid at room temperature for $5 \mathrm{~min}$ with $1 \mathrm{~mL}$ of naphthylethylenediamine dichloride, $0.1 \%$ $\mathrm{w} / \mathrm{v})]$. The mixture was incubated at room temperature for $30 \mathrm{~min}$ and the absorbance of reddish-purple colour change was read at 540 $\mathrm{nm}$.

Acetylcholinesterase assay

Acetylcholinesterase activity was performed according to the method of Ellman et al. (1961). The principle of this method was based on the measurement of the rate of producton of thiocholine as acetylthiocholine is hydrolyzed. This was accomplished by the continuous reaction of the thiol with 5, 5dithiobis -2-nitrobenzoate ion to produce the yellow anion of 5- thio-2-nitro-benzoic acid (II). The rate of colour production read at 412 $\mathrm{nm}$ was directly proportional to acetylcholinesterase activity. Briefly, $25 \mu \mathrm{L}$ of supernatant was added to a cuvette containing $2.925 \mu \mathrm{L}$ of $0.1 \mathrm{M}$ phosphate buffer (pH 8.0), $25 \mu \mathrm{L}$ of $8 \mathrm{mM}$ of DTNB and $25 \mu \mathrm{L}$ of 
$45 \mathrm{mM}$ acetylcholine iodide at room temperature $(27 \mathrm{C})$. The contents in the cuvette were mixed, and the absorbance was read continuously at intervals of $30 \mathrm{sec}$ for 2 $\min$ at $412 \mathrm{~nm}$. Acetylcholinestrase activity was expressed as nmol/mg/min.

\section{Malondialdehyde determination}

The concentrations of malondialdehyde in serum and the supernatants of gill, liver and brain were evaluated using the method of Buege and Aust (1978). The thiobarbituric acid reactive substances (TBARS) assay measures lipid peroxides and aldehydes, such as malondialdehyde (MDA) in the cell, culture media and cell lysate. MDA combined with thiobarbituric acid (TBA) in a 1:2 ratio to form fluorescent adduct that is read at $530 \mathrm{~nm}$. Briefly, to $1.0 \mathrm{~mL}$ of the sample (serum/supernatant) was added to $2.0 \mathrm{~mL}$ of TCA -TBA - HCl reagent [15 \% (w/v), TCA, $0.375 \%(\mathrm{w} / \mathrm{v})$ TBA and $0.25 \mathrm{~N} \mathrm{HCl}$. The contents were boiled for $15 \mathrm{~min}$, cooled and centrifuged at 10,000 g for $10 \mathrm{~min}$ to remove the precipitate. The absorbance was read at $535 \mathrm{~nm}$ using the reagent blank. The concentration of MDA was expressed as unit/mg tissue

Hepatic enzyme markers and alkaline phosphatase assay

Alanine aminotransferase (ALT) and Aspartate aminotransferase (AST) activities were determined using the methods of Reitman and Frankel (1957). Aspartate aminotransferase catalyses the formation of oxaloacetate and glutamate from aspartate and $\alpha$-oxoglutarate. The unstable oxaloacetate spontaneously decarboxylates to pyruvate. The pyruvate is reacted with 2, 4dinitrophenylhydrazine. The absorbance of the resulting brown colour due to the dinitrophenylhyrazone is read under alkaline condition at $546 \mathrm{~nm}$.

ALT catalyzes L-alanine and $\alpha$ ketoglutarate to form pyruvate and glutamate. The pyruvate is then reacted with 2, 4dinitrophenyl-hydrazine to form 2,4dinitrophenyl-hydrazone. The addition of sodium hydroxide dissolves this complex, and allows 2,4-dinitrophenyl-hydrazine to be read at $546 \mathrm{~nm}$ which is proportional to ALT activity.

Alkaline phosphatase was assayed with the method of Roy (1970). Alkaline phosphatase acts upon the 2-amino-2-methyl1-propanol buffered sodium thymolphthalein monophosphate. The addition of an alkaline reagent stops enzyme activity and simultaneously develops a blue chromogen which is measured at $590 \mathrm{~nm}$ and is proportional to the enzyme activity. These assays (liver enzyme markers) were carried out using commercial kits (Randox Laboratories, Ardmore, UK).

Statistical analysis

The mean \pm SD of each group was calculated. Data were analyzed using One - way Analysis of Variance (ANOVA), followed by Duncan's Multiple Range Test (DMRT) to compare the treated groups with the control. Difference between means were considered significant when $\mathrm{p}<0.05$. Statistical analysis was performed using SPSS version 16 (SPSS, Inc Chicago, Illinois, USA).

\section{Results}

The concentration of total protein in serum, gill and liver significantly reduced $(\mathrm{P}<0.05)$ as glyphosate concentration increases as compared with the control. However, in the brain tissue, an increase in the total protein 
concentration was observed. Although, this elevation in total protein concentration was only significant $(\mathrm{P}<0.05)$ for fish exposed to $60 \mathrm{mg} / \mathrm{L}$ and $80 \mathrm{mg} / \mathrm{L}$ compared with the control (Table 1).

The activities of superoxide dismutase (SOD) were elevated $(\mathrm{P}<0.05)$ in all tissues (gill, liver and brain) of Clarias gariepinus exposed to $60 \mathrm{mg} / \mathrm{L}$, but decreased in fish exposed to $80 \mathrm{mg} / \mathrm{L}$ and $100 \mathrm{mg} / \mathrm{L}$ in these tissues (Table 2). Serum SOD activity significantly reduced $(\mathrm{P}<0.05)$ with increased glyphosate concentration (Table 2).
Activities of catalase (CAT) in gills of experimental fish (groups B, C and D) were not altered significantly as compared to the control group. Liver CAT activity decreased $(\mathrm{P}<0.05)$ in exposed fish as compared with the control. An initial insignificant increase in CAT activity of brain was observed in Clarias gariepinus exposed to $60 \mathrm{mg} / \mathrm{L}$ of glyphosate herbicide but significantly reduced $(\mathrm{P}<0.05)$ as exposure to glyphosate increased to 80 $\mathrm{mg} / \mathrm{L}$ and $100 \mathrm{mg} / \mathrm{L}$ (Table 2).

There was a significant reduction $(\mathrm{P}<$ 0.05) in the levels of reduced glutathione

Table 1: Concentration of total protein in serum, gills, liver and brain of Clarias gariepinus exposed to different concentrations of glyphosate herbicide

\begin{tabular}{ccccc}
\hline Groups & Serum (g/dl) & Gill (g/dl) & Liver (g/dl) & Brain (g/dl) \\
\cline { 2 - 5 } A & $3.11 \pm 0.17^{\mathrm{a}}$ & $1.28 \pm 0.14^{\mathrm{a}}$ & $3.34 \pm 0.23^{\mathrm{a}}$ & $0.58 \pm 0.05^{\mathrm{a}}$ \\
B & $2.59 \pm 0.51^{\mathrm{b}}$ & $1.37 \pm 0.26^{\mathrm{b}}$ & $2.49 \pm 0.31^{\mathrm{b}}$ & $1.10 \pm 0.16^{\mathrm{b}}$ \\
C & $2.67 \pm 0.30^{\mathrm{b}}$ & $1.20 \pm 0.18^{\mathrm{a}}$ & $2.02 \pm 0.60^{\mathrm{c}}$ & $1.14 \pm 0.18^{\mathrm{b}}$ \\
D & $2.59 \pm 0.22^{\mathrm{b}}$ & $1.02 \pm 0.22^{\mathrm{c}}$ & $1.71 \pm 0.78^{\mathrm{c}}$ & $0.81 \pm 0.32^{\mathrm{a}}$ \\
\hline
\end{tabular}

Values are expressed as mean \pm standard deviation; $n=5$. Means not showing the same superscript alphabet in a given column differ significantly at $\mathrm{P}<0.05$.

Group A = Control; Group B = Clarias gariepinus induced with $60 \mathrm{mg} / \mathrm{L}$ of glyphosate; Group C = Clarias gariepinus induced with $80 \mathrm{mg} / \mathrm{L}$ of glyphosate; Group D = Clarias gariepinus induced with $100 \mathrm{mg} / \mathrm{L}$ of glyphosate.

Table 2: Activities of superoxide dismutase and catalase in serum, gills, liver and brain of Clarias gariepinus exposed to different concentration of glyphosate herbicide

\begin{tabular}{llllllll}
\hline & \multicolumn{3}{l}{ Superoxide dismutase (Unit/g tissue) } & & \multicolumn{3}{l}{ Catalase (Unit/g tissue) } \\
\cline { 2 - 8 } Groups & Serum & Gills & Liver & Brain & Gills & Liver & Brain \\
\hline A & $39.31 \pm 2.17^{\mathrm{a}}$ & $40.76 \pm 3.86^{\mathrm{a}}$ & $41.39 \pm 3.65^{\mathrm{a}}$ & $40.97 \pm 3.77^{\mathrm{a}}$ & $16.61 \pm 0.34^{\mathrm{a}}$ & $21.21 \pm 1.44^{\mathrm{a}}$ & $23.76 \pm 2.93^{\mathrm{a}}$ \\
B & $37.99 \pm 3.67^{\mathrm{a}}$ & $45.04 \pm 5.54^{\mathrm{b}}$ & $44.89 \pm 5.60^{\mathrm{b}}$ & $44.81 \pm 5.48^{\mathrm{b}}$ & $16.28 \pm 0.02^{\mathrm{a}}$ & $18.64 \pm 1.40^{\mathrm{b}}$ & $25.44 \pm 2.15^{\mathrm{a}}$ \\
C & $28.79 \pm 2.88^{\mathrm{b}}$ & $38.37 \pm 4.19^{\mathrm{a}}$ & $29.34 \pm 4.80^{\mathrm{c}}$ & $37.61 \pm 5.09^{\mathrm{c}}$ & $16.29 \pm 0.06^{\mathrm{a}}$ & $19.49 \pm 1.69^{\mathrm{a}}$ & $21.24 \pm 2.79^{\mathrm{b}}$ \\
D & $20.65 \pm 1.03^{\mathrm{c}}$ & $20.33 \pm 2.68^{\mathrm{c}}$ & $20.25 \pm 2.68^{\mathrm{d}}$ & $19.97 \pm 2.51^{\mathrm{d}}$ & $16.25 \pm 0.05^{\mathrm{a}}$ & $19.39 \pm 0.91^{\mathrm{a}}$ & $18.51 \pm 1.91^{\mathrm{c}}$ \\
\hline
\end{tabular}

Values are expressed as mean \pm standard deviation; $\mathrm{n}=5$. Means not showing the same superscript alphabet in a given column differ significantly at $\mathrm{P}<0.05$.

Group A = Control; Group B = Clarias gariepinus induced with $60 \mathrm{mg} / \mathrm{L}$ of glyphosate; Group C = Clarias gariepinus induced with $80 \mathrm{mg} / \mathrm{L}$ of glyphosate; Group D = Clarias gariepinus induced with $100 \mathrm{mg} / \mathrm{L}$ of glyphosate 
Table 3: Levels of reduced glutathione in blood, gills, liver and brain of Clarias gariepinus exposed to glyphosate herbicide

\begin{tabular}{ccccc}
\hline & $\mathrm{A}$ & $\mathrm{B}$ & $\mathrm{C}$ & $\mathrm{D}$ \\
\cline { 2 - 5 } Blood $(\mathrm{mg} \%)$ & $100.34 \pm 2.20^{\mathrm{a}}$ & $73.01 \pm 1.78^{\mathrm{b}}$ & $74.31 \pm 3.37^{\mathrm{b}}$ & $72.17 \pm 4.96^{\mathrm{b}}$ \\
Gills $(\mu \mathrm{M})$ & $8.63 \pm 0.47^{\mathrm{a}}$ & $5.95 \pm 0.93^{\mathrm{b}}$ & $7.61 \pm 0.54^{\mathrm{c}}$ & $5.48 \pm 0.37^{\mathrm{b}}$ \\
Liver $(\mu \mathrm{M})$ & $4.74 \pm 0.33^{\mathrm{a}}$ & $5.60 \pm 1.00^{\mathrm{b}}$ & $5.89 \pm 0.89^{\mathrm{c}}$ & $4.44 \pm 0.90^{\mathrm{a}}$ \\
Brain $(\mu \mathrm{M})$ & $9.56 \pm 0.78^{\mathrm{a}}$ & $5.62 \pm 1.30^{\mathrm{b}}$ & $6.21 \pm 1.26^{\mathrm{b}}$ & $5.48 \pm 0.38^{\mathrm{b}}$ \\
\hline
\end{tabular}

All values are expressed as mean \pm SD of five replicates. Values followed by different alphabet superscript on the same row indicates that there is a significant difference at $\mathrm{P}<0.05$

Group A = Control; Group B = Clarias gariepinus induced with $60 \mathrm{mg} / \mathrm{L}$ of glyphosate; Group C = Clarias gariepinus induced with $80 \mathrm{mgL}$ of glyphosate; Group D = Clarias gariepinus induced with $100 \mathrm{mg} / \mathrm{L}$ of glyphosate

Table 4: Activities of glutathione peroxidase and glutathione-S-transferase in gills, liver and brain of Clarias gariepinus exposed to glyphosate herbicide

\begin{tabular}{lllll}
\hline & \multicolumn{4}{c}{ Glutathione Peroxidase $(\boldsymbol{\mu m o l} / \mathbf{m g}$ tissue $/ \mathbf{m i n})$} \\
\cline { 2 - 5 } Tissues & $\mathrm{A}$ & $\mathrm{B}$ & $\mathrm{C}$ & $\mathrm{D}$ \\
Gills & $20.45 \pm 0.92^{\mathrm{a}}$ & $22.36 \pm 1.30^{\mathrm{ab}}$ & $25.63 \pm 2.78^{\mathrm{bc}}$ & $27.94 \pm 1.43^{\mathrm{c}}$ \\
Liver & $41.42 \pm 2.30^{\mathrm{a}}$ & $40.11 \pm 1.56^{\mathrm{a}}$ & $39.35 \pm 1.95^{\mathrm{a}}$ & $38.49 \pm 2.79^{\mathrm{a}}$ \\
Brain & $16.59 \pm 1.08^{\mathrm{a}}$ & $17.45 \pm 1.82^{\mathrm{a}}$ & $13.55 \pm 1.76^{\mathrm{b}}$ & $8.79 \pm 0.92^{\mathrm{c}}$
\end{tabular}

Glutathione- S- transferase ( $\mu \mathrm{mol} / \mathrm{mg}$ tissue/minute)

\begin{tabular}{lllll} 
Gills & $39.26 \pm 0.99^{\mathrm{a}}$ & $38.13 \pm 0.82^{\mathrm{a}}$ & $35.12 \pm 0.77^{\mathrm{b}}$ & $36.39 \pm 0.44^{\mathrm{b}}$ \\
Liver & $33.52 \pm 1.75^{\mathrm{a}}$ & $35.79 \pm 2.22^{\mathrm{ab}}$ & $39.12 \pm 0.60^{\mathrm{b}}$ & $37.86 \pm 2.26^{\mathrm{b}}$ \\
Brain & $35.33 \pm 0.40^{\mathrm{a}}$ & $37.12 \pm 0.74^{\mathrm{b}}$ & $36.53 \pm 0.82^{\mathrm{ab}}$ & $37.48 \pm 0.96^{\mathrm{b}}$ \\
\hline
\end{tabular}

All values are expressed as mean \pm SD of five replicates. Values followed by different alphabet superscript on the same row indicate that there is a significant difference at $\mathrm{P}<0.05$.

Group A = Control; Group B = Clarias gariepinus induced with $60 \mathrm{mg} / \mathrm{L}$ of glyphosate; Group C = Clarias gariepinus induced with $80 \mathrm{mgL}$ of glyphosate; Group D = Clarias gariepinus induced with $100 \mathrm{mg} / \mathrm{L}$ of glyphosate

(GSH) in the blood, gills, liver and brain of Clarias gariepinus exposed to varying concentrations of glyphosate herbicide as compared with the control fish (Table 3).

The activities of glutathione peroxidase (GPx) in gill tissues increased $(\mathrm{P}<0.05)$ as compared with the control. However, a progressive reduction in the liver and brain GPx activities has been recorded as compared with the control with respect to increased exposure to glyphosate concentration (Table 4).

Glutathione-S-transferase (GST) activity in gill decreased $(\mathrm{P}<0.05)$ as compared with the control fish. Increase in the concentration of glyphosate from $60 \mathrm{mg} / \mathrm{L}$ to $100 \mathrm{mg} / \mathrm{L}$ led to a significant elevation $(\mathrm{P}<0.05)$ of liver and brain GST activities as compared with the control fish (Table 4).

Concentrations of nitric oxide increased significantly $(\mathrm{P}<0.05)$. (NO) in gill (only at $100 \mathrm{mg} / \mathrm{L}$ ) and brain tissues of fish exposed to glyphosate as compared to the control fish (Table 5). However, NO concentration was not significantly altered in the liver of Clarias gariepinus. In serum NO decreased significantly after 80 and $100 \mathrm{mg} / \mathrm{L}$ glyphosate (Table 5). Acetylcholinesterase (AChE) activities in the serum, gills and brain of Clarias gariepinus exposed to varying concentrations of glyphosate herbicide showed no significant 
Table 5: Concentration of nitric oxide in serum, gills, liver and brain of Clarias gariepinus induced with glyphosate herbicide

\begin{tabular}{ccccc}
\hline & $\mathrm{A}$ & $\mathrm{B}$ & $\mathrm{C}$ & $\mathrm{D}$ \\
\cline { 2 - 5 } Serum (\%) & $25.57 \pm 4.26^{\mathrm{a}}$ & $24.70 \pm 3.61^{\mathrm{a}}$ & $20.47 \pm 1.42^{\mathrm{b}}$ & $15.91 \pm 3.75^{\mathrm{b}}$ \\
Gill (\%) & $18.06 \pm 1.23^{\mathrm{a}}$ & $15.30 \pm 1.49^{\mathrm{a}}$ & $17.05 \pm 0.73^{\mathrm{a}}$ & $30.53 \pm 3.54^{\mathrm{b}}$ \\
Liver (\%) & $28.88 \pm 2.05^{\mathrm{a}}$ & $28.67 \pm 1.63^{\mathrm{a}}$ & $29.26 \pm 1.87^{\mathrm{a}}$ & $31.36 \pm 2.22^{\mathrm{a}}$ \\
Brain (\%) & $23.06 \pm 1.76^{\mathrm{a}}$ & $44.10 \pm 3.99^{\mathrm{b}}$ & $46.70 \pm 4.47^{\mathrm{b}}$ & $55.33 \pm 1.73^{\mathrm{c}}$
\end{tabular}

All values are expressed as mean \pm SD of five replicates. Values followed by different alphabet superscript on the same row indicates that there is a significant difference at $\mathrm{P}<0.05$.

Group A = Control; Group B = Clarias gariepinus induced with $60 \mathrm{mg} / \mathrm{L}$ of glyphosate; Group C = Clarias gariepinus induced with $80 \mathrm{mg} / \mathrm{L}$ of glyphosate; Group D = Clarias gariepinus induced with $100 \mathrm{mg} / \mathrm{L} \mathrm{of}$ glyphosate

Table 6: Activities of acetylcholinesterase in serum, brain, liver and gill of Clarias gariepinus exposed to different concentrations of glyphosate herbicide

\begin{tabular}{lcccc}
\hline Groups & Serum $\left(^{*}\right)$ & Gill $(*)$ & Liver $\left(^{*}\right)$ & Brain $\left(^{*}\right)$ \\
\cline { 2 - 5 } A & $11.97 \pm 0.02^{\mathrm{a}}$ & $12.01 \pm 0.06^{\mathrm{a}}$ & $11.75 \pm 0.27^{\mathrm{a}}$ & $12.06 \pm 0.20^{\mathrm{a}}$ \\
B & $11.99 \pm 0.01^{\mathrm{a}}$ & $11.96 \pm 0.01^{\mathrm{a}}$ & $11.95 \pm 0.05^{\mathrm{b}}$ & $11.99 \pm 0.02^{\mathrm{a}}$ \\
C & $11.98 \pm 0.01^{\mathrm{a}}$ & $11.97 \pm 0.01^{\mathrm{a}}$ & $11.97 \pm 0.02^{\mathrm{b}}$ & $12.00 \pm 0.01^{\mathrm{a}}$ \\
D & $11.98 \pm 0.02^{\mathrm{a}}$ & $11.99 \pm 0.02^{\mathrm{a}}$ & $11.95 \pm 0.03^{\mathrm{b}}$ & $11.98 \pm 0.34^{\mathrm{a}}$
\end{tabular}

\footnotetext{
Values are expressed as mean \pm standard deviation; $\mathrm{n}=5$. Means not showing the same superscript alphabet in a given column differ significantly at $\mathrm{P}<0.05 .\left({ }^{*}\right)=\mathrm{nmol} / \mathrm{mg} / \mathrm{min}$

Group A = Control; Group B = Clarias gariepinus induced with $60 \mathrm{mg} / \mathrm{L}$ of glyphosate; Group C = Clarias gariepinus induced with $80 \mathrm{mg} / \mathrm{L}$ of glyphosate; Group D = Clarias gariepinus induced with $100 \mathrm{mg} / \mathrm{L}$ of glyphosate
}

change as compared with control fish. Significant $(P<0.05)$ inhibition of AChE was noticed in the liver of fish exposed to glyphosate as compared with the control (Table 6).

The concentrations of malondialdehyde (MDA) in the serum, liver and brain tissues of fish exposed to glyphosate were elevated $(\mathrm{P}<$ 0.05) as compared with the control fish (Table 7). MDA concentrations in the gills of fish exposed to $100 \mathrm{mg} / \mathrm{L}$ glyphosate herbicide were significantly lower $(\mathrm{P}<0.05)$ as compared with the control fish (Table 7).

The activities of hepatic enzyme markers alanine and aspartate aminotransferases (ALT and AST) and alkaline phosphatase (ALP) were significantly $(\mathrm{P}<0.05)$ elevated in the serum of Clarias gariepinus exposed to glyphosate herbicide as compared with the control fish.

\section{Discussion}

It is an agreed fact that agrochemicals contamination which includes a variety of herbicides is a crisis of worldwide attention, and aquatic habitats are continuously being exposed to herbicide pollutants especially glyphosate (Kelly et al., 2018). This exposure is contemplated a low risk to aquatic ecosystems and may reach freshwater via spray drift, surface run-off and/or soil leachate (Siemering et al., 2008; Contardo-Jara et al., 2009). Fishes could perhaps, be exposed 
Table 7: Concentration of malondialdehyde in serum, gills, liver and brain of Clarias gariepinus exposed to glyphosate herbicide

\begin{tabular}{lcccc}
\hline & \multicolumn{3}{c}{ Concentration (Unit/mg tissue) } \\
\cline { 2 - 5 } Groups & Gill & Liver & Brain & Serum \\
\hline A & $2.22 \pm 0.39^{\mathrm{a}}$ & $2.12 \pm 0.30^{\mathrm{a}}$ & $0.86 \pm 0.26^{\mathrm{a}}$ & $1.84 \pm 0.62^{\mathrm{a}}$ \\
B & $2.26 \pm 0.39^{\mathrm{a}}$ & $2.65 \pm 0.36^{\mathrm{b}}$ & $0.95 \pm 0.22^{\mathrm{a}}$ & $1.73 \pm 0.23^{\mathrm{b}}$ \\
C & $2.96 \pm 0.76^{\mathrm{a}}$ & $2.89 \pm 0.34^{\mathrm{b}}$ & $1.02 \pm 0.42^{\mathrm{b}}$ & $2.68 \pm 0.89^{\mathrm{b}}$ \\
D & $1.93 \pm 0.61^{\mathrm{b}}$ & $2.98 \pm 0.59^{\mathrm{b}}$ & $1.69 \pm 0.36^{\mathrm{b}}$ & $1.92 \pm 0.76^{\mathrm{c}}$
\end{tabular}

Values are expressed as mean \pm standard deviation; $n=5$. Means not showing the same superscript alphabet in a given column differ significantly at $\mathrm{P}<0.05$.

Group A = Control; Group B = Clarias gariepinus induced with $60 \mathrm{mg} / \mathrm{L}$ of glyphosate; Group C = Clarias gariepinus induced with $80 \mathrm{mg} / \mathrm{L}$ of glyphosate; Group D = Clarias gariepinus induced with $100 \mathrm{mg} / \mathrm{L}$ of glyphosate

Table 8: Activities of alanine aminotransferase, aspartate aminotransferas and alkaline phosphatase in serum of Clarias gariepinus exposed to glyphosate herbicide

\begin{tabular}{lccc}
\hline \multirow{3}{*}{ Groups } & \multicolumn{3}{c}{ Concentration (U/L) } \\
\cline { 2 - 4 } & $\begin{array}{c}\text { Alanine } \\
\text { aminotransferase }\end{array}$ & $\begin{array}{c}\text { Aspartate } \\
\text { aminotransferase }\end{array}$ & $\begin{array}{c}\text { Alkaline } \\
\text { phosphatase }\end{array}$ \\
\hline $\mathrm{A}$ & $7.79 \pm 1.19^{\mathrm{a}}$ & $8.36 \pm 1.09^{\mathrm{a}}$ & $846.42 \pm 13.66^{\mathrm{a}}$ \\
$\mathrm{B}$ & $23.28 \pm 2.89^{\mathrm{b}}$ & $9.28 \pm 1.29^{\mathrm{b}}$ & $1122.67 \pm 12.12^{\mathrm{b}}$ \\
$\mathrm{C}$ & $23.22 \pm 4.69^{\mathrm{b}}$ & $8.90 \pm 1.38^{\mathrm{a}}$ & $959.92 \pm 20.83^{\mathrm{c}}$ \\
$\mathrm{D}$ & $21.16 \pm 3.66^{\mathrm{c}}$ & $11.00 \pm 1.59^{\mathrm{c}}$ & $1210.90 \pm 23.13^{\mathrm{d}}$ \\
\hline
\end{tabular}

Values are expressed as mean \pm standard deviation; $\mathrm{n}=5$. Means not showing the same superscript alphab et in a given column differ significantly at $\mathrm{P}<0.05$.

Group A = Control; Group B = Clarias gariepinus induced with $60 \mathrm{mg} / \mathrm{L}$ of glyphosate; Group C = Clarias gariepinus induced with $80 \mathrm{mg} / \mathrm{L}$ of glyphosate; Group D = Clarias gariepinus induced with $100 \mathrm{mg} / \mathrm{L}$ of glyphosate

to contamination doses of glyphosate which is used in different times on different crop patterns in the same regions and therefore, rivers/streams/ponds/swamps receive this contaminant continuously. In the aquatic environment, glyphosate may induce disturbances at cellular and biochemical levels in fish, and assessment of such changes in biochemical enzymes activities as biomarkers could serve as an association between the effects of glyphosate exposure and risk assessment (Dey et al., 2016). Toxicity of glyphosate-based herbicides in fish including metabolic, oxidative, neurotoxic, genotoxic and haematological parameters has been reported (Modesto and Martinez, 2010 a; Guilherme et al., 2014; Samanta et al., 2014; Sinhorin et al., 2014; Braz -Mota, et al., 2015; Dey et al., 2016; Sobjak et al., 2017; Kurhaluk, 2019). However, the dose-dependant effect of Uproot in fish have not been reported.

In this present study, Clarias gariepinus was exposed to $60 \mathrm{mg} / \mathrm{L}, 80 \mathrm{mg} / \mathrm{L}$ and 100 $\mathrm{mg} / \mathrm{L}$ of glyphosate herbicide for 14 days in ambient environment our laboratory and some biochemical parameters including the activities of acetylcholinesterase (AChE), antioxidant defense enzymes, nitric oxide (NO), hepatic enzyme markers (alanine 
aminotransferase

(ALT),

aspartate aminotransferase (AST) and alkaline phosphatase (ALP)) as well as protein content was evaluated in serum, gills, liver and brain tissues of fish. Total protein concentration in serum, gills and liver of exposed fish were significantly reduced in fish exposed to different concentrations of glyphosate as compared to the control fish. However, the protein content of the brain tissues were elevated in exposed fish. The fundamental role of protein in the architecture and physiology of living organism has been reported (Adams et al., 1990). Protein gives information on the regular energy mobilization of an animal and show relationship with the effect of contamination in these organisms and its catabolism is activated in energy production in fish (David et al., 2004), Reduction in protein level in the serum, gills and liver tissues of Clarias gariepinus after glyphosate exposure could indicate protein catabolism for meeting the high energy demand for augmentation of defense mechanism of fish against herbicidal stress as a compensatory response. Again, since carbohydrate reserve is decreased during stress condition to accommodate the high energy demand (Sudhanshu and Ajay, 2009) and fish have very limited amount of carbohydrate, the next alternative source of energy is protein to meet the increased energy requirement occasioned by a pollutant. Exposure to glyphosate may have initiated metabolic stress in fish and consequently higher energy demands for metabolic purposes. Impaired food intake, increased energy cost of homeostasis, tissue repair and detoxification mechanism during stress could also cause reduction in total protein content of an organism (Neff, 1995).
Alkaline phosphtase (ALP) together with alanine aminotransferase (ALT) and aspartate aminotransferase (AST) provide an indicator of the degree of inflammation, possible causes of hepatocellular damage, and distortion of the plasma membrane and endoplasmic recticulum (Whitehead et al., 1999; Cappo et al., 2002). The present study indicated that exposure of Clarias gariepinus to Uproot significantly increased the activities of these enzymes (ALP, ALT and AST) in serum of the fish which may be partly due to hepatic damage resulting from glyphosate inducedoxidative insults in the hepatocytes.

An excellent measure of the condition of fish is the assessment of the oxidative stress level (Sinha et al., 2014) which is understood as a disturbance in the pro- and antioxidant balance (Yadav et al., 2015) and could lead to unfavourable changes such as increases in the level of lipid peroxidation processes as well as oxidative damage to protein and DNA (Kolakowska and Bartosz, 2010). During oxidative stress, ROS such as superoxide radical and hydroxyl radical are produced. The first line of defense antioxidants to curb the menace of ROS is superoxide dismutase (SOD), catalase (CAT) and glutathione peroixdase (GPx) (Ighodaro and Akinloye, 2018). SOD catalytically scavenges superoxide anion and catalase, hydrogen peroxide. In this study, a decrease in the activities of SOD was observed in all tissues with increase in the rate/ concentration of exposure to the glyphosate herbicide, while catalase was relatively stable except in the brain tissue where its activity was significantly reduced in fish exposed to $100 \mathrm{mg} / \mathrm{L}$ glyphosate compared with the control animal. Reduction in SOD activity with respect to exposure to higher glyphosate 
concentrations may be related to over utilization of SOD due to the high production of superoxide anions. Increased production of nitric oxide (NO) in fish tissues exposed to glyphosate has been noticed in this study which could also lead to a possible decline in the activities of SOD, since NO can react with superoxide radical to form peroxynitrite anion (Sawyer and Valentine, 1981), which could also lead to the nitration of SOD (Ischinopoulos et al., 1992). The rivalry of SOD and NO for superoxide radical exists, and of critical concern is the rate constant for the reaction of superoxide radical and NO to produce peroxynitrite which is one order of magnitude surpassing that of SOD - catalysed superoxide radical dismutation (Radi, 2018). Therefore, it could be argued that at higher concentration of Uproot exposure, the NO produced reacted more with superoxide anion, thus reducing the induction of SOD activity. Peroxynitrite is also viewed as a strong oxidant (Beckman, 1990; Wang and Zweier, 1996) which encourages both nitration and hydroxylation of different bioorganic molecules (Beckman and Koppenol, 1996).

The dismutation product, hydrogen peroxide from the reaction of SOD, is reduced to water and oxygen by CAT (McCord and Fridovich, 1969). CAT activities in the gills and liver of exposed fish were comparable with the control fish. This could be as a result of the inhibition of CAT by high production of superoxide anion (Kono and Fridovich, 1982; Bagnyukova et al., 2006). Superoxide anion is small enough to gain entry to the hemes of catalase and would convert the resting enzyme to the ferro-oxy state (compound III) which is known to be inactive (Chance, 1949).
The high activities of glutathione peroixdase (GPx) in these tissues (gills and brain) could also explain the reduction of CAT, since GPx has been reported to catalysed the reduction of lipid peroxide to corresponding alcohols and free hydrogen peroxide to water by using reduced glutathione (GSH) (Sedaghatfard et al., 2016). From this study it is evident that reduced glutathione was being utilized in all tissues investigated. GPX contains a molecule of selenocysteine in its active site, which is considered to participate directly in electron donation to the peroxide substrate and become oxidized in the process. GSH is used to reproduce the reduced form of the selenocystein by GPx (Ursini et al., 1995).

The potency of the scavenging abilities of the antioxidant enzymes are more pronounced in gills of exposed fish which showed lower concentration of malondialdehyde as compared with the control. MDA has been reported as a marker/measure of free radical damage to lipid, oxidative stress with cytotoxic, genetoxic, mutagenic and carcinogenic properties (Leliuna, 2010; Pocwierz - Kotus et al, 2013).

Glutathione S-transferase (GST) activity plays a vital role in the detoxification of oxidative stress products as well as in the conjugation of glutathione to xenobiotic metabolite to aid their excretion (Schlenk et al., 2008). An elevated activity of GST was observed in liver and brain tissues of exposed fish. This could indicate a defense response to chemical or oxidative stress in cells (Van der Oost et al., 2003). Reduced GST activity in the gills of fish exposed to higher concentrations of the glyphosate herbicide - Uproot, may be connected with over utilization of GSH in that tissue; since the gill remains the first contact 
point with the external environment and the greatest surface area of the fish in contact with the external environment.

Acetylcholinesterase (AChE) activity is a well confirmed specific biomarker of exposure of fish to organophosphate and carbamate insecticides (Monserrat et al, 2002; Pfeifera et al., 2005). Several studies also have shown that formulation containing glyphosate can also inhibit AChE activity in fish (Glusczak et al., 2006; 2007; Modesto and Martinez, 2010 b). Results of this study indicate that AChE activity was only inhibited in hepatic tissues, but were comparable in the serum, gill and brain tissues, although, with lower values. The length of time of exposure to the herbicide may be of importance when considering the inhibitory effect of glyphosate on fish.

\section{Conclusion}

In this study, it was established that the various concentrations $(60,80$, and 100 $\mathrm{mg} / \mathrm{L}$ ) of Uproot used in the experiment led to significant reduction in total protein concentration. Increased production of NO in tissues of exposed fish may have led to the decrease SOD activity, since NO reacts with superoxide radical anion at a faster rate than SOD. GPx enzyme showed more effectiveness in scavenging hydrogen peroxide than catalase whose activities seemed to have been inhibited by the superoxide anion. GST tended to detoxify glyphosate in gills as evident in its utilization of reduced GSH, while exposure of fish to glyphosate did not appreciably inhibit acetylcholinesterase activity. This may be due to the duration of exposure. In all, the induction of NO and impaired activities of the antioxidant enzymes suggested a disruption of normal antioxidant response in Clarias gariepinus exposed to glyphosate, and these biomarkers could be used as indicators of aquatic environmental contamination.

\section{References}

Adams SM, Shugart LR, Sonthworth GR and Hinton DE. (1990) Application of bioindicators in assessing the heal th of fish populations experiencing contaminant stress. In: Biomarkers of Environmental contamination. McCarrthy, JF and Shugart LR (eds), Lewis Publishers. Boca Raton., pp. 333- 353.

Ahmad I, Hamid T, Fatima M, Chand HS, Jain SK, Athar M and Raisudin S. (2000) Induction of hepatic antioxidants in freshwater catfish (Channa punctatus Bloch) is a biomarker of paper mill effluent exposure. Biochim Biophys Acta 1523: 37- 48.

Bagny ukova TV, Chahrak OI and Lushchak VI. (2006) Coordinated response of old fish antioxidant defenses to environmental stress. Aquat Toxicol. 78: $325-331$.

Beckman JS. (1990) Ischaemic injury mediator. Nature 345: 27- 28.

Beckman JS and Koppenol WH. (1996) Nitric oxide, superoxide and peroxynitrite: the good, the bad, and ugly. Am J Physiol. 271: C1424 -C1437.

Beutler E. (1984) Red cell metabolism: Manual of Biochemical Methods. Third edition. Grune and Stratton, Inc., p.187.

Braz - Mota S, Sadauskas - Henrique H, Duarte RM, Val AL and Almeida -Val VMF. (2015) Roundup exposure promotes gills and liver impairments, DNA dam age and inhibition of brain cholinergic activity in the Amazon teleost fish Colossoma macropomum . Chemosphere 135: 53 -60.

Buege JA and Aust SD. (1978) Microsomal lipid peroxidation. Methods Enzymol. 52: 302- 305.

Cappo JA, Mussart NB and Fiorannelli SA. (2012) Physiological variation of enzymatic activities in blood of bull frog, Rana catesbeiana (Shaw, 1802). Rev Vet. 12/13: 22- 27.

Chance B. (1949) The primary and secondary compounds of catalase and methyl or ethyl hydrogen peroxide: II. Kinetics and activity. J Biol Chem. 179: 1341-1369.

Contardo-Jara V, Klingelmann E and Wiegand C. (2009) Bioaccumulation of glyphosate and its formulation Roundup Ultra in Lubriculus variegates and its effects on biotransformation and antioxidant enzymes. Environ Pollut. 157: 57- 63. 
David M, Mushigeri SB, Shivakumar R and Philip GH. (2004) Response of Cyprinus carpio (Linn.) to sublethal concentration of cypermethrin: alteration in protein metabolic profiles. Chemosphere 56: 347-352.

Dey S, Samanta P, Pal S, Mukherjee AK, Kole D and Ghosh AR. (2016) Integrative assessment of biomarker responses in tel eostean fishes exposed to glyphosate-based herbicide (Excel Mera 71). Em erg Contam. 2: 191- 203.

Doumas BT, Bayse DD, Carter RJ, Peters JrT and Schaffer R. (1981) A candidate reference method for determination of total protein in serum. 1. Development and validation. Clin Chem. 27:1642- 1650

Duke SO and Powles SB. (2008) Glyphosate: a once-ina century herbicide. Pest Mang Sci. 64: 319 -325.

Ellman GL. (1959). Tissue sulfhydryl groups. Arch Biochem Biophys. 82: 70- 77.

Ellman GL, Courtney KD, Andres VJ and Featherstone RM. (1961) A new and rapid colorimetric determination of acetylcholinesterase activity. Biochem Pharmacol. 7: 88- 95.

Glusczak L, Miron DS, Crestani M, Fonseca MB, Pedron FA, Duarte MF and Vieira VLP. (2006) Effect of glyphosate herbicide on acetylcholinesterase activity and metabolic and hematological parameters in piava (Leporinus obtusidens). Ecotoxicol Environ Saf. 65: 237- 241.

Glusczak L, Miron DS, Moraes BS, Simoes RR, Schetinger MRC, Morsch VM and Loro Vl. (2007) Acute effects of glyphosate herbicide on metabolic and enzymatic parameters of silver catfish (Rhamdia quelen). Comp Biochem Physiol.146C: 519- 524.

Goss SP, Hogg N, O'Leary VJ, Wilson MT and Moncada S. (1997) The effect of nitric oxide releas e rates on the oxidation of human low density lipoprotein. J Biol Chem. 272: 21647- 21653.

Green LC, Wegner DA, Glogowski J, Skipper PL, Wishnok JS and Tannenbaum SR. (1982) Analysis of nitrate, nitrite and nitric oxide in biological fluids. Anal Biochem. 126: 131-138.

Guilherme S, Santos MA, Gaivao I and Pacheco M. (2014) Are DNA-damaging effects induced by herbicide formulations (Roundup and Garlon) in fish transient and reversible upon cessation of exposure? Aquat Toxicol. 155: 213- 221.

Habig WR, Pabst MJ and Jakoby WB. (1974) Glutathione transferase: a first enzymatic step in mercaturic acid formation. J Biol Chem. 249: 7130-7139.
Ighodaro OM and Akinloye OA. (2018) First line defence antioxidants - superoxide dismutase (SOD), catalase (CAT) and glutathione peroxidase (GPx): Their fundamental role in the entire antioxidant grid. Alexandria J Med. 54: 287-293.

Ischiropoulos $\mathrm{H}$, Zhu L, Chen J, Tsai J, Martin C, Smith CD and Beckan JS. (1992) Peroxynitrite-mediated tyrosine nitration catalysed by superoxide dismutase. Arch Biochem Biophys. 298: 431-437.

Kaplan JH and Groves J. (1972) Liver and blood cell catal ase activity in tumor-bearing mice. Cancer Res. 32: $1190-1194$.

Kelly DW, Poulin R, Tompkins DM and Townsend CR. (2018) Synergistic effects of glyphosate formulation and parasite infection on fish malformations and survival. J Appl Ecol. 47: 498-504.

Kolakowska A and Bartosz G. (2010) Antioxidants. In: Chameical, Biological and Functional Aspect of Food Lipid, (eds.)Sikorski Z and Kolakowska A, CRC Press, Boca Raton, FL, USA, pp 163-184.

Kono Y and Fridovich I. (1982) Superoxide radicals inhibit catalase. J Biol Chem. 257: 5751- 5754.

Kurhaluk N. (2019) Formation of an antioxidant profile in the sea trout (Salmo trutta m. trutta. L.) from the Slupia River. Zoology 133: 54- 65.

Leliuna E. (2010) Assessment of genetic structure of sea trout (Salmo trutta trutta L.) populations in the Nemunas River tributaries based on mitochondrial DNA variation. Acta Zool Lituan. 20: 112-118.

McCord JM and Fridovich I. (1969) Superoxide dismutase, an enzymatic function for erythrocuprein (Chemocuprien). J Biol Chem. 244: 6049- 6055.

Misra HP and Fridovich I. (1972) The role of superoxide ion in the auto-oxidation of epinephrine and a simple essay for superoxide dismintase. J Biol Chem. 247: 3170 -3175.

Modesto KA amd Martinez CBR. (2010 a) Roundup causes oxidative stress in liver and inhibits acetylcholinestrase in muscle and brain of the fish Prochilodus lineatus. Chemosphere 78: 294- 299.

Modesto KA and Martinez CBR. (2010 b) Effects of Roundup Transorb on fish: Hematology, antioxidant defenses and acetylcholinesterase activity. Chemosphere 81: 781- 787.

Moin VM. (1986) Simple and specific method of measurement of glutathione peroxidase activity in the erythrocutes. Laboratornoe delo 12: 724-727.

Monserrat JM, Bianchini A and Bainy ACD. (2002) Kinetic and toxicological characteristics of 
acetylcholinesterase from the gills of oysters (Crassostrea rhizophorae) and other aquatic species. Mar Environ Res. 54: 781- 785.

Monserrat JM, Martinez PE, Geracitano LA, Amado LL, Martins CMG, Pinho GLL, Chaves IS, Ferreira Cravo M, Lima JV and Bianchini A. (2007) Pollution biomarkers in estuarine animals: critical review and new perspectives. Comp Biochem Physiol. Part C 146: 221- 234.

Neff JM. (1985) Use of biochemical measurements to detect pollution-mediated damage to fish. In: Aquatic toxicology and hazard assessment. (eds.) Cardwel RD Purdy R and Bahner RC, Philadelphia. Am Soc Test Mat. pp 155- 181.

Oruc EO, Sevgiler Y and Uner N. (2004) Tissuespecific oxidative stress respons es in fish expos ed to 2, 4-D and azinphosmethyl. Comp Biochem Physiol. Part C 137: 43-51.

Osioma E, Akanji MA and Arise RO. (2013) Hepatic enzyme markers and proteins in serum and some selected tissues in Clarias gariepinus from swamp around Kokori-Erhoike Oil field, Nigeria. J Res Biol. 3: 984 -992.

Osioma E and Iniaghe PO. (2019) Concentration of heavy metals in water, sediments and tissues of Clarias gariepinus from earthen ponds in Kolo Creek Communities in Bayelsa State, Niger Delta. Nigeria. Asia J Water Environ Pollut. 16 : 97-106.

Parvez S and Raisuddin S. (2005) Protein carbonyl: novel biomarkers of exposure to oxidative stressinducing pesticides in freshwater fish Channa punctata (Bloch). Environ Toxicol Pharmacol. 20: 112-117.

Pfeifera S, Doris S and Dippner JW. (2005) Effect of temperature and salinity on acetyleholinesterase activity, a common pollution biomarker in Mytilus $s p$. from the South- western Baltic Sea. J Exp Mar Biol Ecol. 320: 93-103.

Pocwierz-Kous H, Bernas R, Debowski P, Kent MP, Lien S, Kesler M, Titov S, Leliuna E, Jespersen $\mathrm{H}$, Drywa A and Wenne R. (2013) Genetic differentiation of So utheast Baltic populations of sea trout inferred from single nucleotide polymorphism. Ani Gen. 45: 96-104.

Radi R. (2018) Oxygen radicals, nitric oxide, and peroxynitrite: Redox pathways in molecular medicine. PNAS 115: 5839- 5848.

Reitman S and Frankel SA. (1957) A colorimetric method for the determination of serum glutamic oxaloacetic and glutamic pyruvic transaminases. Am. J Clin Pathol. 28; 56- 63.
Roy AV. (1970) Rapid method for determining alkaline phosphatase activity in serum with thymolph thal ein monophosphate. Clin Chem. 16: 431- 436.

Samanta P, Pal S, Mukherjee AK and Ghosh AR. (2014) Biochemical effects of glyphosate based herbicide, Excel Mera 71 on enzyme activities of acetylcholinesterase (AChE), lipid peroxidation (LPO), catalase (CAT), glutathione -S- transferase (GST) and protein content on teleostean fishes. Ecotoxicol Environ Saf. 107: 120-125.

Sancho E, Ceron JJ and Ferrando MD. (2000) Cholinesterase activity and hematological parameters as biomarkers of sublethal molinate exposure in Anguilla Anguilla. Ecotoxicol Environ Saf. 46: 81- 86 .

Sawyer DT and Valentine J. (1981) How super is superoxide? Acc Chem Res. 14: 393- 400.

Schlenk D, Celander M, Gallagher EP, George S, James M, Kullman SW, Van der Hurk $\mathrm{P}$ and Willet K. (2008) Biotransformation in fishes. In: The Toxicology of Fishes, (eds). Di Giulo RT and Hinton DE, CRC Press, Taylor and Francis Group, pp 153- 234.

Sedaghatfard F, Razavi SA, Hedayati M, Razmi N and Rahnama A. (2016) Glutathione peroxidase activity assay with colorimetric method and microplate reading format and comparison with chemiluminescence method. Eur Online J Natr Soc Sci. 5: 15-21.

Siemering GS, Hayworth JD and Greenfield BK. (2008) Assessment of potential aquatic herbicide impacts to California aquatic ecosystems. Arch Environ Contam Toxicol. 55: 415-431.

Sinha AK, Abd Elgawad H, Giblen T, Zinta G, De Rop M, Asard H, Blust R and De Boeck G. (2014) Antioxidant defences are modulated differently in three freshwater teleosts in response to ammonia induced oxidative stress. PLos ONE 9: e95319.

Sinhorin VDG, Sinhorin AP, Teixeira JMS, Mileski PCH, Moreira PSA, Kawas hita NH, Baviera AM and Loro VL. (2014) Effects of the acute exposition to glyphosate-based herbicide on oxidative stress parameters and antioxidant responses in a hybrid Amazon fish surubim (Pseudoplatystoma sp). Ecotoxicol Environ Saf. 106: 181- 187.

Sobjak TM, Romao S, do Nascimento CZ, dos Santos AFP, Vogel L and Guimaraes ATB. (2017) Assessment of the oxidative and neurotoxic effects of glyphosate pesticide on the larvae of Rhamdia quelen fish. Chemosphere 18: 267-275.

Sudhanshu T and Ajay S. (2009) Changes in some biochemical parameters in the liver and muscle of 
Colisa fasciatus due to toxicity of ethanolic extract of Nerium indicum Mill (Lal Kaner) Latex. Nat Prod Rad. 8: 48- 54.

Ursini F, Maiorino M, Brigelius-Flohe R, Aumann KD, Roveri A, Schomburg D and Flohe L. (1995) Diversity of glutathione peroxidases. Methods Ezymol. 252: 38- 53.

Van der Oost R, Beyer J and Vermeulen NPE. (2003) Fish bioaccumulation and biomarkers in environmental risk assessment: A review. Environ Toxicol Pharmacol. 13: 57-149.

Wang P and Zweier JI. (1996) Measurement of nitric oxide and peroxynitrite generation in the postischemic heart. Evidence for peroxynitrite- mediated reperfusion injury. J Biol Chem. 217: 29223- 29230.

Whitehead MW, Hawkes ND, Hainswort I and Kingham JG. (1999) A prospective study of the cause of notably raised aspartate transaminase of liver origin. Gut 45: 129-133.

Yadav SS, Kumar R, Khare P and Tripathi M. (2015) Oxidative stress biomarkers in the freshwater fish; Heteropneustes fossilis (Bloch) exposed to sodium fluoride: antioxidant defense and role of ascorbic acid. Toxicol Intern. 22: 71-76. 